\title{
Antagonistic potentiality of native rhizobacterial isolates against root rot disease of okra, incited by Rhizoctonia solani
}

\author{
A. Adhikari' ${ }^{1}$, S. Dutta ${ }^{2 *}$, S. Nandi ${ }^{2}$, I. Bhattacharya ${ }^{2}$, M. De Roy ${ }^{3}$, G. Sarkar ${ }^{3}$ and T. Mandal ${ }^{1}$ \\ ${ }^{1}$ Department of Biotechnology, O.I.S.T., VIdyasagar University, Paschim Medinipur, India. \\ ${ }^{2}$ Department of Plant Pathology, BCKV, Mohanpur, Nadia, India. \\ ${ }^{3}$ Soil Testing Laboratory, PORS, Berhampore, India. \\ Accepted 9 January, 2013
}

\begin{abstract}
Among seventy isolates, antagonistic twenty one representing biovars of Pseudomonas fluorescens (biovars I, II, III, and V) were collected from the rhizosphere of okra, chilli, ground nut, brinjal, cabbage and tomato from different agro-ecological regions of West Bengal and were subjected to evaluate for their antifungal activity under in vitro condition against Rhizoctonia solani, the most important soilborne plant pathogen two isolates, PF-8 and PF-7 effectively inhibited the mycelial growth of Rhizoctonia solani (72.05 and $68.25 \%$, respectively) in dual culture method. The vigour index of okra was also recorded maximum for the isolate PF-8 (2415.7) followed by PF-7 (2063.25). Mechanisms of fungal inhibition were elucidated by tracing secondary-metabolite production of the rhizobacterial isolates. Most of the isolates expressed a specific mechanism of antagonism, as represented by production of pigments, Siderophores, cyanide (HCN), Indole Acetic acid (IAA) and Salicylic Acid (SA) production, and Phosphate solubilization. Rhizobacterial isolate PF-8 was found to be effective as seed and soil treatment for management of root rot disease of okra. The antagonistic nature of fluorescent pseudomonads against fungal pathogens can be assigned to design a potential candidate for development of agriculture sector to be used in biological control of soil borne plant pathogens.
\end{abstract}

Key words: Fluroscent pseudomonads, secondary metabolites, Rhizoctonia solani, okra root rot.

\section{INTRODUCTION}

Okra, which is also known as "Bhind", is one of the important vegetables of India in general and West Bengal in particular with production of 0.662 million tones from 58,400 ha with an average productivity of 11.4 t.ha $^{-1}$. A number of fungi, bacteria, viruses, nematodes and insects attack this crop. The total loss of vegetable on this account has been estimated up to 20 to $30 \%$ but if the pathogens are allowed to develop, this loss may increase up to 80 to $90 \%$ (Hamer and Thompson, 1957). Among the diseases, okra root rot incited by Rhizoctonia solani is the most serious problems for okra cultivation,

\footnotetext{
${ }^{*}$ Corresponding author: E-mail: subrata_mithu@yahoo.co.in
}

especially in the post-kharif under Gangetic Alluvial Region of West Bengal. The biological control of plant pathogenic fungi has received considerable attention as an alternative strategy through the use of saprophytic micro flora.

Pseudomonades have been found in large populations, which inhabit in the rhizosphere of several agriculture crops. For the survival of plant growth promoting rhizobacteria, the production of plant growth promoting substances is an important trait. PGPR (Plant Growth Promoting Rhizobacteria) enhance plant productivity by a range of mechanisms. The plant growth promoted by PGPR is still now pandemonium mechanism and not clearly understood, but is thought to include some beneficial directs and indirects effect resulting to several 
hypothesis such as production of antibiotics, siderophores, or cyanhidric acid ( $\mathrm{HCN})$, that decrease the growth of phytopathogens and other deleterious microorganisms, production of plant growth regulators, or improvements in plant nutrient uptake (Glick, 1995; Myoungsu et al., 2005) and production of phytohomones such as auxins (Asghar et al., 2002), cytokinins (Arkhipova et al., 2005) and gibberellins (GutierrezManero et al., 2001; Joo et al., 2004) as well as through the solubilization of phosphate minerals (Freitas et al., 1997) are usually believed to be involved. Root colonization by PGPR may induce the production of plant growth substances by the plant (Patten and Glick, 2002).

This present investigation was undertaken to find out and characterize the effective isolates of fluorescent pseudomonads and possible mechanisms for antagonism elucidated by determining secondary-metabolites production and its application for management of root rot disease of okra.

\section{MATERIALS AND METHODS}

\section{Collection of soil samples and isolation, characterization and identification of rhizobacterial isolates}

Fluorescent pseudomonads were isolated from the soil collected from the rhizosphere of different crops with King's medium B (KMB) (King et al., 1954). The antagonistic rhizobacterial isolates were characterized on the basis of their morphological (cell shape, cell arrangement, gram reaction), cultural (colony type, pigment production) and biochemical identification keys of Bossis (1995) for Pseudomonas sp. Pseudomonads were identified to species and biovars on the basis of oxidase, arginine dihydrolase, denitrificacation, gelatine hydrolysis, levan production, and acid production from trehalose, utilization of tryptophane and L-tartrate (Bossis et al., 2000). The rhizobacterial isolates were bioassayed for their ability to promote/inhibit seedling growth on okra using the method as described by ISTA (1966). These bacterial colonies were tested for their antagonistic activity against $R$. solani by dual culture technique.

\section{In vitro antagonistic activity against soil borne fungal pathogen}

For each treatment three replications were used. Percent inhibition over control was calculated by using the formula as follows:

$I=\frac{C-T}{C} \times 100$

$\mathrm{I}=$ percent inhibition of mycelium; $\mathrm{C}=$ growth of mycelium in control, and $\mathrm{T}=$ growth of mycelium in treatment.

\section{Secondary metabolites production by bacterial isolates}

Bacterial strains producing an antagonism towards pathogen $(R$. solani), were tested for the production of secondary metabolites like production of IAA (Gordon and Weber, 1951), Siderophore (Reeves et al., 1983), HCN (Lorck, 1948; modified by Alstrom, 1989), Salicylic acid (Meyer et al., 1992) and Phosphate solubilization (Ammonium phosphomolybdate method).

\section{Preparation of mass inoculums}

$250 \mathrm{ml}$ of nutrient sucrose broth $(0.1 \%$ sucrose) was inoculated with PF-8 isolates and mass culturing was done in rotary shaker incubator for $60 \mathrm{~h}$ at $28 \pm 2^{\circ} \mathrm{C}$ and the bacterial cultures were mixed in sterilized talc containing $1 \%$ CMC. Talc mixed culture containing $\left(3.5 \times 10^{8} \mathrm{cfu} / \mathrm{g}\right.$ of talc mixed product) was used for seed treatment as well as soil treatment.

Effect of rhizobacterial isolates on management of root rot disease of okra

The experiment was conducted in C-Block farm, BCKV, Kalyani during pre-kharif season 2011. Seven treatments (Table 4) were used in three replications in RBD in $9 \mathrm{~m}^{2}$ plot size. Standard package of practices were maintained except for disease management measures. Disease incidence (\%) was calculated based on the following formula:

(Number of infected plants / Total number of plants) $\times 100$

Fruits picking was done in seven days intervals and total plot yield was obtained ( $\mathrm{kg} / 9 \mathrm{~m}^{2}$ plot).

\section{Statistical analysis}

Correlation and regression were calculated based on the dependable (percentage of growth inhibition of pathogen) and independable variables (IAA, HCN, SA, Siderophore production and phosphate solubilization). A Hierarchical cluster analysis with the UPGMA algorithm was performed with the SPSS 10.0 analysis system.

\section{RESULTS AND DISCUSSION}

Twenty one out of the seventy isolates isolated from different crops of different regions (Table 1) exhibited antagonistic activity towards $R$. solani. Using the phenotypical criteria (Bossis et al., 2000) seven, ten and three isolates were identified as $P$. fluorescens biovar I, $\mathrm{V}$, III respectively. Only one isolate of PF- 23 identified as $P$. fluorescens biovar II (Table 2). Most of the antagonistic bacteria ( $P$. fluorescens biovar $V$ ) were isolated from new gangetic alluvial region and remaining ( $P$. fluorescens biovar I ) from terai, old alluvial and red \& lateritic region of West Bengal (Table 1).

\section{In vitro antagonism}

The demonstration of higher inhibition level was elucidated by restriction of growth toward $R$. solani by fluorescent pseudomonads. Antifungal activity shown by these isolates is given in the Table 4 which reveals that there is variation in the antifungal activity among the isolates. The effective antagonistic rhizobacterial isolates exhibited antagonistic activity in the range of 42 to $72 \%$ and significantly highest antagonistic activity against $R$. solani was observed by PF-8 isolates $(72.05 \%$ inhibition) in dual culture method. The data depicted in the Table 3 
Table 1. List of location, rhizosphere of rhizobacterial isolates and antagonistic isolates.

\begin{tabular}{|c|c|c|c|c|}
\hline Location & Lat and long & $\begin{array}{l}\text { Soil } \\
\text { Rhizosphere }\end{array}$ & No. of isolates & $\begin{array}{l}\text { Antagonistic } \\
\text { isolates }\end{array}$ \\
\hline Purulia (Hura) & $23.32208^{\circ}$ N Lat; $86.65498^{\circ}$ E Long & Okra & 5 & PF2 \\
\hline Daspur (W. Midnapore) & $22.60464^{\circ} \mathrm{N}$ Lat; $87.72351^{\circ} \mathrm{E}$ Long & Chilli & 6 & PF3 \\
\hline N. Dinajpur (Chopra) & $26.42204^{\circ} \mathrm{N}$ Lat; $88.28401^{\circ} \mathrm{E}$ Long & Brinjal & 7 & PF4,PF5 \\
\hline Kalyani (Nadia) & $22.98515^{\circ}$ N Lat; $88.43335^{\circ}$ E Long & Okra & 8 & PF7,PF8,PF23 \\
\hline Beharampore (Murshidabad) & 24.16912 N Lat; 88.32502 E Long & Okra & 4 & PF9 \\
\hline Hoogly (polba) & $22.96489^{\circ} \mathrm{N}$ Lat; $88.31884^{\circ} \mathrm{E}$ Long & Potato & 5 & PF10 \\
\hline Malda & $25.06209^{\circ} \mathrm{N}$ Lat; $88.14974^{\circ} \mathrm{E}$ Long & Bean & 3 & PF11 \\
\hline Purulia (Hura) & $23.32208^{\circ} \mathrm{N}$ Lat; $86.65498^{\circ} \mathrm{E}$ Long & Citrus & 4 & PF13,14 \\
\hline Kalyani (Nadia) & $22.98515^{\circ} \mathrm{N}$ Lat; $88.43335^{\circ} \mathrm{E}$ Long & Potato & 4 & PF15 \\
\hline Kalyani (Nadia) & $22.98515^{\circ} \mathrm{N}$ Lat; $88.43335^{\circ} \mathrm{E}$ Long & Cabbage & 3 & PF16 \\
\hline Hoogly (polba) & $22.96489^{\circ} \mathrm{N}$ Lat; $88.31884^{\circ} \mathrm{E}$ Long & Brinjal & 3 & PF17 \\
\hline Daspur (W. Midnapore) & 22.60464 N Lat; $87.72351^{\circ} \mathrm{E}$ Long & Ground nut & 3 & PF18 \\
\hline Burdwan & $23.2500^{\circ} \mathrm{N}$ Lat; $87.8500^{\circ} \mathrm{E}$ Long & Tomato & 3 & PF19 \\
\hline Kalyani (Nadia) & $22.98515^{\circ} \mathrm{N}$ Lat; $88.43335^{\circ} \mathrm{E}$ Long & Brinjal & 4 & PF20 \\
\hline Panskura (East Midnapore) & $22.42841^{\circ} \mathrm{N}$ Lat; $87.72411^{\circ} \mathrm{E}$ Longitude & Groundnut & 3 & PF21 \\
\hline Kalyani (Nadia) & $22.98515^{\circ} \mathrm{N}$ Lat; $88.43335^{\circ}$ E Long & Chilli & 3 & PF22 \\
\hline Purulia (Baghmundi) & $23.12^{\circ} \mathrm{N}$ Lat; $86.3^{\circ} \mathrm{E}$ Long & Okra & 2 & PF24 \\
\hline
\end{tabular}

Table 2. Biochemical characteristics for the identification of isolates belonging to $P$. fluorescens and $P$. putida (Bossis et al., 2000).

\begin{tabular}{|c|c|c|c|c|c|c|c|c|c|c|}
\hline Isolate & Fluorescence & Arginine & Oxidase & Tabac & Gelatine & Trehalose & Lev & Deni & L-ara & L(+)tart + \\
\hline PF2 & + & + & + & - & + & + & + & - & NA & NA \\
\hline PF3 & + & + & + & - & + & - & - & - & NA & NA \\
\hline PF4 & + & + & + & - & + & + & + & - & NA & NA \\
\hline PF5 & + & + & + & - & + & + & + & - & NA & NA \\
\hline PF7 & + & + & + & - & + & - & - & + & NA & NA \\
\hline PF8 & + & + & + & - & + & - & - & - & NA & NA \\
\hline PF9 & + & + & + & - & + & - & - & - & NA & NA \\
\hline PF10 & + & + & + & - & + & - & - & - & NA & NA \\
\hline PF11 & + & + & + & - & + & & & & NA & NA \\
\hline PF13 & + & + & + & - & + & + & + & - & NA & NA \\
\hline PF14 & + & + & + & - & + & - & - & + & NA & NA \\
\hline PF15 & + & + & + & - & + & - & - & + & NA & NA \\
\hline PF16 & + & + & + & - & + & - & - & - & NA & NA \\
\hline PF17 & + & + & + & - & + & - & - & - & NA & NA \\
\hline PF18 & + & + & + & - & + & - & - & - & NA & NA \\
\hline PF19 & + & + & + & - & + & - & - & - & NA & NA \\
\hline PF20 & + & + & + & - & + & + & + & - & NA & NA \\
\hline PF21 & + & + & + & - & + & - & - & - & NA & NA \\
\hline PF22 & + & + & + & - & + & - & - & - & NA & NA \\
\hline PF23 & + & + & + & - & + & + & + & + & + & + \\
\hline PF24 & + & + & + & - & + & + & + & + & NA & NA \\
\hline
\end{tabular}

L-ara, L-arabinose; Den., Denitrification; Lev., Levan; L(+) tart., L(+) tartrate; +, positive result; -, negative result; NA, not applicable.

indicated that the vigour index based on germination percentage, root length and shoot length was also recorded maximum for the isolate PF-8 (2415.7) followed by PF-7 (2063.25). Variation in the antifungal activity of the Fluorescent pseudomonads isolates was also been observed by other workers. Tripathi and Johri (2002) observed in vitro inhibition of Colletotrichum dermatium, $R$. solani and Sclerotium rolfsii by fluorescent 
Table 3. Effect of seed bacterization with native rhizobacterial isolates and their combinations on seed germination, root length, shoot length and vigour index.

\begin{tabular}{lcccc}
\hline Name of the antagonists & Germination $(\%)$ & Root length $\mathbf{( c m})$ & Shoot length $(\mathbf{c m})$ & Vigour index \\
\hline PF2 & 58.3 & 11.5 & 4.6 & 938.63 \\
PF3 & 66.7 & 10.3 & 3.9 & 947.14 \\
PF4 & 58.3 & 10.1 & 2.5 & 734.58 \\
PF5 & 66.7 & 11.8 & 2.9 & 980.49 \\
PF7 & 91.7 & 16.4 & 6.1 & 2063.25 \\
PF8 & 83.3 & 21.5 & 7.5 & 2415.70 \\
PF9 & 66.7 & 13.6 & 5.4 & 1267.30 \\
PF10 & 75.0 & 12.9 & 3.1 & 1200.00 \\
PF11 & 66.7 & 14.2 & 3.3 & 1167.25 \\
PF13 & 66.7 & 10.7 & 2.4 & 873.77 \\
PF14 & 58.3 & 11.2 & 2.9 & 822.03 \\
PF15 & 66.7 & 12.1 & 3.7 & 1053.86 \\
PF16 & 66.7 & 12.3 & 3.1 & 1027.18 \\
PF17 & 13.1 & 5.4 & 1233.95 \\
PF18 & 66.7 & 15.1 & 3.3 & 1227.28 \\
PF19 & 66.7 & 8.4 & 2.8 & 652.96 \\
PF20 & 58.3 & 11.1 & 3.2 & 1072.50 \\
PF21 & 75.0 & 8.8 & 4 & 746.24 \\
PF22 & 58.3 & 9.3 & 3.7 & 867.10 \\
PF23 & 66.7 & 10.1 & 2.4 & 687.94 \\
PF24 & 58.3 & 2.4 & 734.58 \\
Control & 58.3 & 2.4 & 2.1 & 612.15 \\
\hline
\end{tabular}

pseudomonads. The data depicted in the Table 3 indicated maximum vigour index based on germination percentage, root length and shoot length for the isolate PF-8 (2415.7) followed by PF-7 (2063.25). The effective rhizobacterial antagonist isolates were selected for further characterization of secondary metabolites traits (Table 4).

\section{Secondary metabolites traits}

Twenty one rhizobacterial isolates were selected for the secondary metabolites trait analysis. They were tested for their ability to produce antifungal metabolites, Phytohormones- IAA, HCN, Siderophores, SA and Phosphate solubilization activity. Significantly higher amount of secondary metabolites were produced by PF-8 and PF-7 isolates as compared with others. The production of IAA was in the range of 19.76 to $137.19 \mu \mathrm{g} / \mathrm{ml}$. Thirteen isolates produced IAA in between 19 and $50 \mu \mathrm{g} / \mathrm{ml}$ and eight isolates produced IAA more than $50 \mu \mathrm{g} / \mathrm{ml}$ amount. Ahamad et al. (2005) also reported the production of IAA by 11 isolates of pseudomonads from different crop plants in the range of 5.34 to $22.4 \mathrm{mg} / \mathrm{ml}$. Similarly Karnwal (2009) also reported the varying amounts of IAA production by fluorescent pseudomonads. Anandaraj and Sarma (2003) reported that growth-promoting strains of fluorescent Pseudomonads were found to synthesize phytohormones viz. IAA and Gibberellic Acid (GA). The production of significant levels of IAA and cause of shoot and root elongation in soybeans are nothing but the application of plant growth promoting rhizobacteria, Pseudomonas sp (Gupta et al., 2002). Thus, this present findings indicated that the eight rhizobacterial isolates having the potentiality of higher production of IAA may be exploited in future for enhancement of plant growth. It was noteworthy that, production of $\mathrm{HCN}$ was important secondary metabolite in terms of pathogen inhibition. All the rhizobacterial isolates of this present study were cyanogenic but the isolates PF- 8 and PF-7 were capable of production of significantly higher amount of $\mathrm{HCN}$. PF8 and PF-7 could be characterized as potential antagonistic isolates in terms of production of higher amount of secondary metabolites traits like $\mathrm{HCN}$, siderophore, SA, IAA and phosphate solubilization activity. In order to predict the antagonistic activity of rhizobacterial isolates with biochemical parameters a linear multiple regression model was developed using different biochemical parameters through stepwise method.

$Y=23.957-0.0574 X 2(I A A)+3.66 .57 X 3(H C N) ; R^{2}=0.890 ; R^{2}{ }_{a d j}=0.878$

$Y=0.0026 X-0.0497 ; R^{2}=0.8479$

HCN production, the single secondary metabolite 
Table 4. Production of secondary metabolites.

\begin{tabular}{|c|c|c|c|c|c|c|}
\hline Isolates & $\begin{array}{l}\text { Growth inhibition } \\
\text { against RS (\%) }\end{array}$ & $\begin{array}{l}\text { IAA production } \\
(\mu \mathrm{g} / \mathrm{ml})\end{array}$ & $\begin{array}{c}\text { HCN production } \\
\text { (Absorbance at } 625 \mathrm{~nm} \text { ) }\end{array}$ & $\begin{array}{l}\text { Siderophore production } \\
(\mu \mathrm{mole} \text { benzoic acid } / \mathrm{ml})\end{array}$ & $\begin{array}{c}\text { Salicylic acid } \\
\text { production }(\mu \mathrm{g} / \mathrm{ml})\end{array}$ & $\begin{array}{l}\text { Phosphate solubilization } \\
\text { ( } \mu \mathrm{g} / \mathrm{ml} \text { culture filtrate) }\end{array}$ \\
\hline PF2 & $63.15^{\mathrm{cd}}(52.62)$ & $24.42^{\mathrm{kl}}$ & $0.111^{\mathrm{d}}$ & $15.0^{\text {cde }}$ & $3.07^{\text {def }}$ & $29.53^{\prime}$ \\
\hline PF3 & $65.1^{\mathrm{c}}(53.79)$ & $43.86^{\mathrm{h}}$ & $0.121^{c}$ & $19.89^{b}$ & $0.465^{i}$ & $67.98^{\mathrm{b}}$ \\
\hline PF4 & $56.1^{g h}(48.50)$ & $76.36^{d}$ & $0.098^{\text {efg }}$ & $11.84^{\text {def }}$ & $1.61^{\mathrm{h}}$ & $27.24^{\prime}$ \\
\hline PF5 & $53.8^{\mathrm{hi}}(47.18)$ & $52.59^{g}$ & $0.091^{\mathrm{fgh}}$ & $10.64^{\text {ef }}$ & $4.33^{b c}$ & $35.03^{k}$ \\
\hline PF7 & $68.25^{\mathrm{b}}(55.70)$ & $81.49^{c}$ & $0.135^{\mathrm{b}}$ & $30.43^{a}$ & $4.99^{b}$ & $105.26^{\mathrm{a}}$ \\
\hline PF8 & $72.05^{\mathrm{a}}(58.08)$ & $137.19^{a}$ & $0.157^{a}$ & $33.65^{\mathrm{a}}$ & $6.0^{\mathrm{a}}$ & $108.59^{a}$ \\
\hline PF9 & $56^{\mathrm{gh}}(48.45)$ & $29.34^{\mathrm{j}}$ & $0.09^{g h}$ & $12.90^{\text {def }}$ & $2.76^{\text {defg }}$ & $53.87^{\mathrm{cd}}$ \\
\hline PF10 & $58.4^{\mathrm{fg}}(49.84)$ & $22.67^{1 \mathrm{~m}}$ & $0.101^{\mathrm{de}}$ & $14.84^{\text {cde }}$ & $1.76^{\mathrm{gh}}$ & $51.34^{\text {de }}$ \\
\hline PF11 & $63.7^{\mathrm{cd}}(52.95)$ & $19.76^{\mathrm{m}}$ & $0.110^{d}$ & $16.18^{\mathrm{bcd}}$ & $2.61^{\text {efgh }}$ & $50.93^{\text {def }}$ \\
\hline PF13 & $54.65^{\mathrm{hi}}(47.65)$ & $74.43^{\text {de }}$ & $0.092^{\text {fgh }}$ & $17.73^{\mathrm{bc}}$ & $2.83^{\operatorname{defg}}$ & $49.2^{\text {defg }}$ \\
\hline PF14 & $44.05^{\prime}(41.58)$ & $72.43^{\mathrm{e}}$ & $0.073^{\mathrm{jk}}$ & $10.87^{\text {ef }}$ & $2.38^{\text {fgh }}$ & $37.84^{\mathrm{jk}}$ \\
\hline PF15 & $55.7^{\text {ghi }}(48.27)$ & $28.25^{\mathrm{jk}}$ & $0.087^{\text {ghi }}$ & $13.44^{\text {cdef }}$ & $3.07^{\operatorname{def}}$ & $45.67^{f g h}$ \\
\hline PF16 & $61.7^{\mathrm{de}}(51.77)$ & $37.95^{i}$ & $0.106^{\mathrm{de}}$ & $12.43^{\operatorname{def}}$ & $3.72^{\mathrm{cd}}$ & $57.33^{\mathrm{C}}$ \\
\hline PF17 & $\left.59.55^{\mathrm{ef}} 50.51\right)$ & $29.10^{\mathrm{j}}$ & $0.091^{\mathrm{fgh}}$ & $13.16^{\text {cdef }}$ & $2.64^{\text {defgh }}$ & $51.49^{\text {de }}$ \\
\hline PF18 & $52.95^{\mathrm{i}}(46.69)$ & $27.74^{\mathrm{jk}}$ & $0.083^{\mathrm{hij}}$ & $10.71^{\text {ef }}$ & $2.06^{\mathrm{fgh}}$ & $45.18^{g h}$ \\
\hline PF19 & $58.85^{\dagger}(50.10)$ & $37.00^{i}$ & $0.081^{\mathrm{hij}}$ & $13.60^{\text {cdef }}$ & $1.55^{\mathrm{h}}$ & $46.09^{\text {efgh }}$ \\
\hline PF20 & $47.25^{\mathrm{k}}(43.42)$ & $23.74^{1}$ & $0.076^{\mathrm{ij}}$ & $12.68^{\text {def }}$ & $3.06^{\text {def }}$ & $42.08^{\mathrm{hij}}$ \\
\hline PF21 & $54.75 h^{\mathrm{i}}(47.73)$ & $64.71^{\dagger}$ & $0.091^{\mathrm{fgh}}$ & $10.40^{\text {ef }}$ & $2.84^{\operatorname{defg}}$ & $44.30^{g h i}$ \\
\hline PF22 & $50.2^{\mathrm{j}}(45.11)$ & $106.04^{b}$ & $0.082^{\mathrm{hij}}$ & $9.58^{f}$ & $3.61^{\text {cde }}$ & $39.19^{\mathrm{ijk}}$ \\
\hline PF23 & $42.05^{\prime}(40.43)$ & $37.10^{i}$ & $0.065^{\mathrm{k}}$ & $9.65^{f}$ & $2.26^{\mathrm{fgh}}$ & $35.83^{k}$ \\
\hline PF24 & $47.9^{\mathrm{jk}}(43.80)$ & $24.93^{\mathrm{kl}}$ & $0.078^{\mathrm{ij}}$ & $11.98^{\text {def }}$ & $2.49^{\text {fgh }}$ & $29.11^{\prime}$ \\
\hline $\operatorname{SEM}( \pm)$ & 0.610 & 0.875 & 0.0748 & 0.998 & 0.2274 & 1.216 \\
\hline$C D(P=0.05)$ & $(1.799)$ & 2.580 & 0.0224 & 2.946 & 0.6707 & 3.586 \\
\hline
\end{tabular}

Value with the same letters indicates they are not significantly different $(\mathrm{p}=0.05)$ by DMRT analysis; all values in parentheses are arc-sine transformed values of percent values.

variables of rhizobacterial isolates can able to explain the variation in antagonistic potentiality of rhizobacterial isolates by $84 \%$ (Figure 1). Based on the stepwise regression equation it was observed that HCN production was one of the most important predictors for evaluation of antagonistic activity of rhizobacterial isolates against soil-borne plant pathogens. Similarly, Ramette et al. (2003) reported that microbial production of $\mathrm{HCN}$ has been reported as an important antifungal trait to control root infecting fungi. The collar rot of sunflower disease suppression by fluorescent pseudomonads was promoted by HCN production (Shivani et al., 2005). The increased production of $\mathrm{HCN}$ by the efficient strain of $\mathrm{P}$. fluorescens contributed to effective inhibition of mycelial growth of Rhizoctonia solani in vitro (Kuklinskysobral et al., 2004) and appears to be a major factor in control of soil-borne disease by Pseudomonas fluorescens CHAO (Jamali et al.,
2009).

The two tailed Pearson's correlation between antagonistic activity of rhizobacterial isolates and their secondary metabolites production revealed that $\mathrm{HCN}$, siderophore production and $\mathrm{P}$ solubilization activity of rhizobacterial isolates were significantly positively correlated with the antagonistic activity of rhizobacterial isolates even at $1 \%$ level (Table 5).

Many $P$. fluorescens isolates are known to 


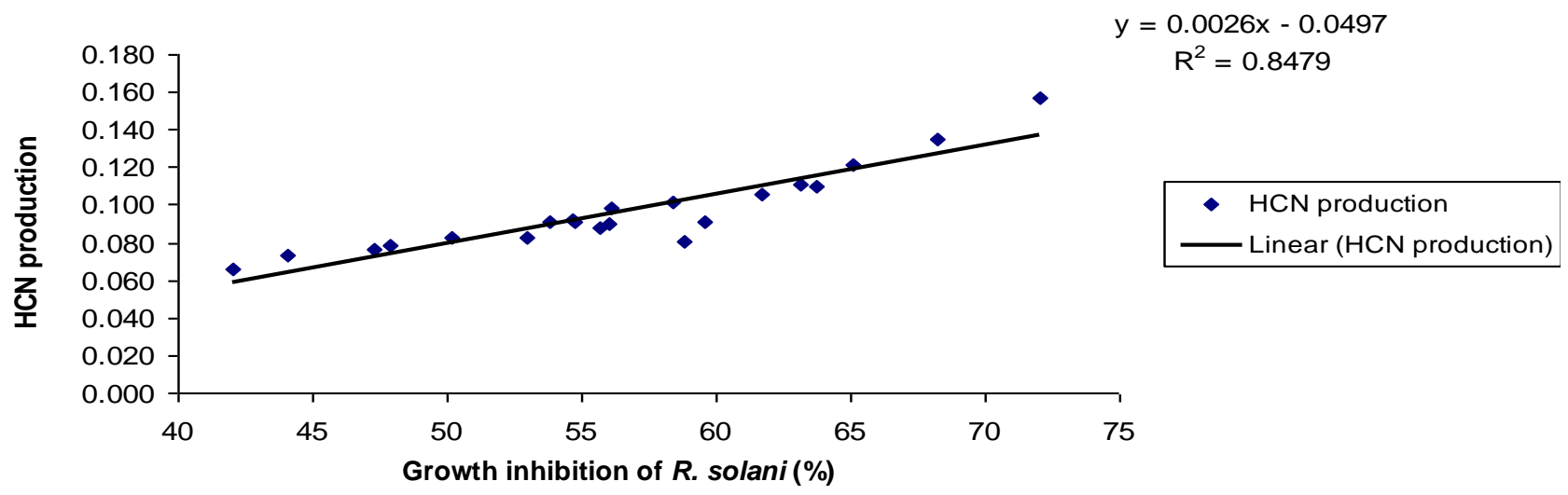

Figure 1. Relationship between $\mathrm{HCN}$ production and antagonistic potentiality of rhizobacterial isolates.

Table 5. Correlation matrix including all the 5 independent variables with the dependent variable (\% Growth inhibition).

\begin{tabular}{lc}
\hline Parameter & Growth inhibition (\%) \\
\hline IAA production & 0.229 \\
HCN production & $0.920^{\star *}$ \\
Siderophore & $0.765^{\star *}$ \\
SA production & 0.331 \\
P-solubilization & $0.724^{\star *}$ \\
Growth inhibition (\%) & 1.00 \\
\hline
\end{tabular}

** Significant at $1 \%$ level of probability $(\mathrm{P}=0.01)$.

secrete fluorescent and yellow-green, water soluble siderophores under iron-limiting conditions (Rosales et al., 1993). Additionally, siderophore mediated competition for iron was shown to be major mechanism of antagonistic activity of fluorescent pseudomonads in the control of some parasitic fungi, limiting iron availability to them (Miethke and Marahiel, 2007). Rassouli et al. (2005) reported that 201 indigenous Pseudomonas spp. isolated from Iranian soils were sidrophore producers in CAS-agar medium.

To date, studies in biological control have focused mainly on fluorescent pseudomonads, producing fluorescent pigments and siderophores like pyoverdin (Haas and Defago, 2005), because of their metabolic versatility, their excellent root colonization ability and antimicrobial metabolites (O'Sullivan and O'Gara, 1992). Similarly, Kumar et al. (2000) reported that the $P$. fluorescens produced siderophores and antifungal metabolites which are involved in the control of phytopathogenic fungi. Salicylic acid (SA) production has been observed for several bacterial strains, and exogenously applied SA can induce resistance in many plant species. Fluorescent pseudo-omonads strains were known to produce salicylic acid (Dowling and O'Gara, 1994), and salicylic acid was a systemic signal molecule inducing disease resistance (Neuenschwander et al.,
1996). Salicylic acid produced by $P$. fluorescens in the rhizosphere is thought to be involved in ISR (Maurhofer et al., 1994). The results of this present investigation (Table 4) regarding SA production accounted to be ranged between 1.55 and $3.61 \mu \mathrm{g} / \mathrm{ml}$, isolate PF-8 being the significantly highest producer $(6.0 \mu \mathrm{g} / \mathrm{ml})$ followed by PF-7 $(4.99 \mu \mathrm{g} / \mathrm{ml})$, are in confirmation with the findings of Nagarajkumar et al. (2004) who reported that 14 strains of Pseudomonads could produce SA and its amount varied from 2 to $16 \mu \mathrm{g} / \mathrm{ml}$.

Gupta et al. (2002) reported Pseudomonas sp. acted as a potent phosphate solublizer. Das et al. (2003) examined the tricalcium phosphate solubilizing activity of $P$. fluorescens and phosphate solubilizing pseudomonads are also reported to suppress damping-off disease in tomato caused by Pythium spp. (Srivastav et al., 2004). Likewise, in this present study, phosphate solubilization activity was noticed to be in the range of 27.24 to 108.59 $\mu \mathrm{g} / \mathrm{ml}$ culture filtrate, PF- 8 and 7 being the significantly greatest solubilizers. Thus from the above finding, it may be concluded that HCN, siderophore production and phosphate solubilizing activity were the three most important secondary metabolites significantly contributed towards the biocontrol potentialities of rhizobacteria.

\section{Effect of rhizobacterial isolates on management of root rot disease of okra}

The data presented in Table 6 revealed that all the treatments were found to be significantly superior over control. Combination of seed treatment and soil application of PF-8 was found to be the most effective methods both in respect to minimizing the root and collar rot disease of okra (52.6\% disease control) and obtaining the highest yield (30.8\% enhancement of yield) (Table 6). The lowest collar rot disease severity of okra was obtained in case of seed plus soil application with carbendazim, however, it was found statistically at par with seed treatment plus soil application of PF-8. Similar 
Table 6. Effect of different treatments on root rots disease and yield of okra.

\begin{tabular}{lccc}
\hline Treatments & Disease incidence (\%) & Disease reduction over control (\%) & Yield \\
\hline T1: Seed treatment with PF-8 & $19.4^{\mathrm{c}}$ & 31.93 & $3.90^{\mathrm{bc}}$ \\
T2: Soil application with PF-8 & $17.5^{\mathrm{d}}$ & 38.71 & $4.05^{\mathrm{ab}}$ \\
T3: T1+T2 & $13.3^{\mathrm{e}}$ & 52.63 & $4.33^{\mathrm{a}}$ \\
T4: Seed treatment with carbendazim & $21.5^{\mathrm{b}}$ & 24.68 & $3.67^{\mathrm{c}}$ \\
T5: Soil Treatment with carbendazim & $17.3^{\mathrm{d}}$ & 39.30 & $3.95^{\mathrm{bc}}$ \\
T6: T4+T5 & $13.1^{\mathrm{e}}$ & 54.03 & $4.15^{\mathrm{ab}}$ \\
T7: Control & $28.5^{\mathrm{a}}$ & & $3.31^{\mathrm{d}}$ \\
SEM \pm ) & 0.1054 & & 0.0525 \\
CD at 5\% & 0.3247 & & 0.161 \\
\hline
\end{tabular}

Value with the same letters indicates they are not significantly different $(p=0.05)$ by DMRT analysis.

observation of plant disease management (Verticillium wilt) through the application of Pseudomonas fluorescens and Pseudomonas putida, was recorded by MercadoBlanco et al. (2004). Bhatia et al. (2005) also reported the reduction of collar rot incident incited by Sclerotium rolfsii with seeds bacterization of fluorescent pseudomonads in sunflower. Several reports evidenced the crucial role of fluorescent Pseudomonads in soil suppressive to fusarium wilt (De Boer et al., 1999) and take-all disease caused by the phytopathogen fungus Gaeumanomyces graminis var. tritici (Weller, 2007).

Yield data presented in the Table 6, for all the treatments were found to be significantly superior over control. The significantly highest yield of okra was recorded in seed plus soil treatment with the native antagonist rhizobacterial PF-8. Similar observations of enhancement of yield were recorded by several workers. Improvement of yield with fluorescent pseudomonads was reported by Rao et al. (1999) in lentil and Ahmadzadeh et al. (2009) in bean.

\section{REFERENCES}

Ahamad F, Ahmad I, Saghir KM (2005). Indole acetic acid production by the indigenous isolates of Azotobacter and fluorescent pseudomonas in the presence and absence of tryptophan. Turk. J. Biol. 29:29-34.

Ahmadzadeh M, Tehrani AS (2009). Evaluation of fluorescent pseudomonads for palnt growth promotion, antifungal activity against Rhizoctonia solani on common bean, and biocontrol potential. Bio. Control. 48. 101-107. Alstrom S, Burns RG (1989). Cyanide production by rhizobacteria as a possible mechanism of plant growth inhibition. Biol. Fertil. Soils. 7: 232-238.

Anandaraj M, Sarma YR (2003). The potential of PGPR in disease management of spices crops. In: $6^{\text {th }}$ International PGPR workshops, 5-10 October 2003, Calicut, India.

Arkhipova TN, Veselov SU, Melantiev Al, Marty NEV, Kudoyerova GR (2005). Ability of bacterium Bacillus to produce cytokinins and to influence the growth and endogenous hormone content of lettuce plants. Plant Soil 272:201-209.

Asghar HN, Zahir ZA, Arshad M, Khaliq A (2002). Releationship between in vitro production of auxins by rhizobacteria and their growth promoting activities in Brassica juncea L. Biol. Fert. Soils 35:231-237.

Bhatia S, Dubey RC, Maheshwari DK. (2005). Enhancement of plant growth and suppression of collar rot of sunflower caused by
Sclerotium rolfsii through characterizaiton. Curr. Microbiol. 45:323327.

Bossis E (1995). Les Pseudomonas fluorescents de la rhizosphère : étude taxonomique et effets sur la croissance de la tomate et du maïs, de la germination à la levée, Thèse de doctorat, Université de Nantes, France. p.143.

Bossis E, Lemanceau P, Latour X, Gardan L (2000). The taxonomy of Pseudomonas fluorescens and Pseudomonas putida: current status and need for revision. Agronomie 20:51-63.

Das K, Katiyar V, Goel R (2003). P-solubilization potential of plant growth promoting Pseudomonas mutant at low temperature. Microbiol. Res. 158:559-562.

De Boer M, Vander sluis I, Van Ioon LC, Bakker HM (1999). Combining fluorescent Pseudomonas spp. strains to enhance suppression of fusarium wilt of radish. European J. Plant Pathol. 105:201-210.

Dowling DN, O'Gara F (1994). Metabolites of Pseudomonas involved in the biocontrol of plant disease. Tib Tech. 12:133-141.

Freitas JR, Banerjee MR, Germida JJ (1997). Phosphate solubulizing bacteria enhance the growth and yield but not phosphorus uptake of canola (Brassica napus L). Biol. Fert. Soils 24:358-364.

Glick BR (1995). The enhancement of plant growth by free living bacteria. Can. J. Microbiol. 41:109-114.

Gordon SA, Weber RP (1951). Calorimetric estimation of indoleacetic acid. Plant growth-promoting rhizobacteria. Biocontrol. Sci. Technol. 11:557-574.

Gupta A, Meyer JM, Goel R (2002). Development of heavy metal resistant mutants of phosphate solubilizing Pseudomonas sp. NBRI 4014 and their characterizaiton. Curr. Microbiol. 45:323-327.

Gutierrez-Manero FJ, Ramos-Solano B, Probanza A, Mehouachi J, Tadeo FR, Talon M (2001). The plant growth-promoting rhizobacteria Bacillus licheniformis produce high amounts of physiologically active gibberillins. Physiologia Plantarum 111:206-211.

Haas D, Défago G (2005). Biological control of soil-borne pathogens by fluorescent pseudomonads. Nature Rev. Microbiol. 3:307-319.

Jamali F, Sharifi-tehrani A, Lutz MI, Maurhofer M (2009). Influence of host plant genotype, presence of a pathogen, and coinoculation with Pseudomonas fluorescens strains on the rhizosphere expression of hydrogen cyanide- and 2,4 diacetylphloroglucinol biosynthetic genes in P. fluorescens biocontrol strain CHA0. Microb. Ecol. 57:267-275.

Hamer C, Thompson T (1957). Vegetable Crops. McGraw Hill Co., Inc. N. X. Toronto, London.

ISTA (1966). International Rules of Seed Testing; Proc. Int. Seed. Test. Assoc. 32:565-589.

Joo GJ, Kim YM, Lee KIJ, Song S, Rhee IK (2004). Growth promotion of red pepper seedlings and the production of gibberellins by Bacillus cereus, Bacillus macroides, Bacillus pumilus. Biotechnol. Lett. 26:487-491.

Karnwal A (2009). Production of indole acetic acid by fluorescent pseudomonas in the presence of L-tryptophan and rice root exudates. J. Plant Pathol. 91(1):61-63.

King EO, Ward MK, Rany DE (1954). Two simple media for the demonstration of pyocyanin and Xuorescein. J. Lab. Clin. Med. 
44:301-307.

Kuklinsky-sobral J, Araujo WL, Mendes R, Geraldi O, Pizzirani-kleiner A, Azevedo JL (2004). Isolation and characterization of soybeanassociated bacteria and their potential for plant growth promotion. Environ. Microbiol. 6:1244-1251.

Kumar G, Sharma RC, Rai SN (2000). Biocontrol of banded leaf and sheath blight of maize by peat based Pseudomonas fluorescens formulation. Indian Phytopathol. 53:190-192.

Lorck H (1948). Production of hydrocyanic acid by bacteria. Physiol. Plant. 1:142-146.

Maurhofer M, Hase C, Meuwly P, M'etraux JP, D' efago G (1994). Induction of systemic resistance of tobacco to tobacco necrosis virus by the root-colonizing Pseudomonas fluorescens strain $\mathrm{CHAO}$ : influence of the gacA gene and of pyover-dine production. Phytopathology 84:139-146.

Mercado-Blanco J, Rodriguez-Jurado D, Hervas A, Timnez-Diaz M (2004). Suppression of verticillium wilt in olive planting stocks by root associated fluorescent pseudomonads. Bicontrol 30:474-486.

Meyer JM, Ajelvandre P, Georges C (1992). Iron metabolism in Pseudomonas: Salicylic acid, a siderophore of Pseudomonas fluorescens CHA0. Biofactors 4:23-27.

Miethke M, Marahiel MA (2007). Siderophore-based iron acquisition and pathogen control. Microbiol. Mol. Biol. Rev. 71:413-451.

Myoungsu P, Chungwoo K, Jinchul Y, Hyoungseok L, Wansik S, Seunghwan K, Tongmin S (2005). Isolation and characterization of diazotrophic growth promoting bacteria from rhizosphere of agricultural crops of Korea. Microbiol. Res. 160:127-133.

Nagarajkumar M, Bhaskaran R, Velazhahan R (2004). Involvement of secondary metaboloties and extracellular lytic enzymes produced by Pseudomonas fluorescens in inhibition of Rhizoctonia solani, the rice, sheath blight pathogen. Microbiol. Res. 159:73-81.

Neuenschwander U, Lawton K, Ryals J (1996). Systemic acquired resistance. In: Plant Microbe interactions (Eds. Stacey G. and Keen N T.), New York, Chapman and Hall I:81-106.

O'Sullivan DJ, O'Gara F (1992). Traits of fluorescent Pseudomonas spp. involved in suppression plant root pathogens. Microbial. Rev. 56:662-676.

Patten CL, Glick BR (2002). Role of Pseudomonas putida indole aceticacid in development of host plant root system. Appl. Environ. Microbiol. 48:3795-3801.
Ramette A, Frapolli M, Defago G, Moneme Y (2003). Phylogeny of HCN synthesis-encoding hon BC genes in biocontrol fluorescent pseudomonas and its relationship with host plant species and $\mathrm{HCN}$ synthesis ability. Mol. Plant interact. 16:525-535.

Rao VS, Sachan IP, Johri BN (1999). Influence of fluorescent pseudomonads on growth and nodulation of lentil (Lens esculentus) in Fusarium infested soil. Indian J. Microbiol. 39:23-29.

Rassouli MH, Khavazi K, Rahimian H, Malakouti MJ, Asadi-Rahmani $\mathrm{H}$ (2005). An evaluation of the potential of indigenous Fluorescent Pseudomonds of wheat rhizosphere for producing siderophore. Iran J. Soil Water Sci. 20:133-143.

Reeves M, Pine L, Neilands JB, Bullows A (1983). Absence of siderophore activity in Legionella spp. grown in iron deficient media. $J$ Bacteriol. 154:324-329.

Rosales AM, Vantomone R, Swings J, De Ley J, Mew TW (1993). Identification of some bacteria from paddy antagonistic to several rice fungal pathogens. J. Phytopathol. (Berl.). 138(3):189-208.

Shivani B, Dubey RC, Maheshwari DK (2005). Enhancement of plant growth and suppression of collar rot of sunflower caused by Sclerotium rolfsii through fluorescent Pseudomonas. Indian Phytopathol. 58(1):17-24.

Srivastav S, Yadav K S, Kundu BS (2004). Phosphate solubilizing pseudomonads suppress damping-off disease in tomato. J. Mycol. Plant Pathol. 34:662-664.

Tripathi M, Johri BN (2002). In vitro antagonistic potential of fluorescent and control of sheath blight of maize caused by Rhizoctonia solani. Indian J. Microbiol. 42:207-214.

Weller DM (2007). Pseudomonas biocontrol agents of soilborne pathogens: looking back over 30 years. Phytopathology 97:250-256. 